\title{
Red blood cell transfusion in the critically ill patient
}

\author{
Christophe Lelubre and Jean-Louis Vincent ${ }^{*}$
}

\begin{abstract}
Red blood cell (RBC) transfusion is a common intervention in intensive care unit (ICU) patients. Anemia is frequent in this population and is associated with poor outcomes, especially in patients with ischemic heart disease. Although blood transfusions are generally given to improve tissue oxygenation, they do not systematically increase oxygen consumption and effects on oxygen delivery are not always very impressive. Blood transfusion may be lifesaving in some circumstances, but many studies have reported increased morbidity and mortality in transfused patients. This review focuses on some important aspects of RBC transfusion in the ICU, including physiologic considerations, a brief description of serious infectious and noninfectious hazards of transfusion, and the effects of $\mathrm{RBC}$ storage lesions. Emphasis is placed on the importance of personalizing blood transfusion according to physiological endpoints rather than arbitrary thresholds.
\end{abstract}

\section{Introduction}

Red blood cell (RBC) transfusion is commonly required in critically ill patients. Several recent, observational, multicenter studies reported that approximately one third of critically ill patients received a blood transfusion at one time or another during their stay in the intensive care unit (ICU) (Table 1). Because of the frequent use of this intervention, it is important for the ICU physician to be aware of recent developments in this continuously evolving field of medicine. In this narrative review, we consider some key aspects of transfusion medicine in the ICU, focusing on aspects relevant to the critically ill patient, including prevalence and reasons for blood transfusion, epidemiology and etiology of anemia in these patients, pathophysiological considerations on tolerance to anemia, and efficacy of RBC transfusion. Safety concerns, including questions of RBC storage and leukoreduction, are then discussed, followed by a proposal for an integrated approach to transfusion decisions and a discussion on economic aspects and alternatives to blood transfusion.

\section{Epidemiology of anemia and red blood cell transfusion in the ICU}

Anemia is common in ICU patients and appears early in the ICU course [1]. In an observational, multicenter,

\footnotetext{
* Correspondence: jlvincen@ulb.ac.be

Department of Intensive Care, Erasme Hospital, Université libre de Bruxelles, Route de Lennik 808, 1070 Brussels, Belgium
}

cohort study in Scotland, $25 \%$ of patients admitted to the ICU had a hemoglobin level $<9 \mathrm{~g} / \mathrm{dl}$ [2]. Similar results were reported in the $A B C$ study [3], in which $29 \%$ of patients had a hemoglobin concentration $<10 \mathrm{~g} /$ $\mathrm{dl}$ on admission. Even in nonbleeding ICU patients, hemoglobin levels tend to decrease early [3]. This decrease is more pronounced in septic than in nonseptic patients [4], at least in part because of their inflammatory response; more frequent blood sampling may also contribute.

Interestingly, anemia and the need to restore adequate oxygen delivery $\left(\mathrm{DO}_{2}\right)$ are the most common indications for transfusion, rather than acute bleeding [3,5-10]. Anemia in the critically ill patient is a multifactorial phenomenon that has been compared to the so-called "anemia of chronic illness" [11]. Apart from evident causes of anemia, such as primary blood losses (e.g., trauma, surgery, gastrointestinal bleeding), multiple other etiologies contribute to its pathophysiology and often coexist in the same patient [11]. These include blood losses related to minor procedures or phlebotomy, and hemodilution secondary to fluid resuscitation. Some studies have suggested that blood sampling may average as much as $40 \mathrm{ml} /$ day $[3,4]$, but the amount of blood required may decrease with technological developments in analytic methods. Other mechanisms for anemia include an inflammatory response with blunted erythropoietin (EPO) production, abnormalities in iron

\section{Springer}


Table 1 Multicenter observational studies of transfusion in general ICU patients

\begin{tabular}{|c|c|c|c|c|c|c|c|}
\hline Author & $\begin{array}{l}\text { Year study was } \\
\text { conducted }\end{array}$ & Country/region & $\begin{array}{l}\text { No. of patients and } \\
\text { number of ICUs }\end{array}$ & $\begin{array}{c}\text { Percentage } \\
\text { transfused in ICU }\end{array}$ & $\begin{array}{c}\text { Pretransfusion } \\
\text { hemoglobin level }\end{array}$ & $\begin{array}{l}\text { Mean no. of units } \\
\text { transfused in ICU }\end{array}$ & $\begin{array}{l}\text { Mean age of } \\
\text { blood (days) }\end{array}$ \\
\hline Hebert et al. [9] & 1993 & Canada & 5,298 patients in $6 \mathrm{ICUS}$ & 25.0 & Mean: $8.6 \pm 1.3 \mathrm{~g} / \mathrm{dl}$ & NS & NS \\
\hline Vincent et al. [3] & 1999 & Western Europe & 3,534 patients in $146 \mathrm{ICUs}$ & 37.0 & Mean: $8.4 \pm 1.3 \mathrm{~g} / \mathrm{dl}$ & $4.8 \pm 5.2$ & $16.2 \pm 6.7$ \\
\hline Rao et al. [6] & 1999 & UK & 1,247 patients in $9 \mathrm{ICUS}$ & 53.0 & $\begin{array}{c}\text { Median: } 8.5 \text { (IQR: 7.9-9) } \\
\text { g/dl }\end{array}$ & $\begin{array}{c}6.75 \text { (hemorrhage) and } 4.25 \\
\text { (anemia) }\end{array}$ & NS \\
\hline Corwin et al. [5] & $2000-2001$ & USA & 4,892 patients in 284 ICUs & 44.0 & Mean: $8.6 \pm 1.7 \mathrm{~g} / \mathrm{dl}$ & $4.6 \pm 4.9$ & $21 \pm 11.4$ \\
\hline Walsh et al. [7] & 2001 & UK (Scotland) & 1,023 patients in $10 \mathrm{ICUs}$ & 39.5 & Median: 7.8 (7.3-8.5) g/dl & $\begin{array}{l}\text { Mean: } 1.87 \text { unit/ICU } \\
\text { admission }\end{array}$ & NS \\
\hline French et al. [10] & 2001 & $\begin{array}{l}\text { Australia and New } \\
\text { Zealand }\end{array}$ & 1,808 patients in 18 ICUs & 19.8 & $\begin{array}{l}\text { Median: } 8.2 \\
\text { (range: } 4.4-18.7 \text { ) g/dl }\end{array}$ & Mean: 4.18 & NS \\
\hline Vincent et al. [34] & 2002 & $\begin{array}{c}\text { Western and Eastern } \\
\text { Europe }\end{array}$ & 3,147 patients in 198 ICUs & 33.0 & Median: $8.2 \mathrm{~g} / \mathrm{dl}$ & $5.0 \pm 5.8$ & NS \\
\hline Westbrook et al. [8] & 2008 & $\begin{array}{l}\text { Australia and New } \\
\text { Zealand }\end{array}$ & 5,128 patients in $47 \mathrm{ICUs}$ & 14.7 & Mean: $7.7 \mathrm{~g} / \mathrm{dl}$ & Median: 2 (IQR: 1-4) & $\begin{array}{l}\text { Median: } 14 \\
\text { (IQR: } 9.5-21.5)\end{array}$ \\
\hline
\end{tabular}


metabolism, and altered proliferation and differentiation of medullar erythroid precursors [11]. As a consequence, $\mathrm{RBC}$ deformability is decreased [12], whereas RBC adherence to the endothelium is increased, especially in septic patients, potentially leading to microcirculatory impairment and tissue hypoxia [13].

\section{Tolerance to anemia in healthy subjects and in the critically ill patient}

Tolerance to anemia is highly dependent on the volume status of the patient, physiological reserve, and the dynamics of the anemia (for example, chronic, such as the anemia of sepsis, versus acute, such as hemorrhagic conditions). Normovolemic anemia is better tolerated than anemia in hypovolemic states (e.g., acute bleeding in trauma patients or surgery) in which cardiac output acutely decreases. In healthy subjects submitted to normovolemic hemodilution, cardiac output increases because of decreased blood viscosity (especially relevant in severe anemia) and increased adrenergic response, allowing tachycardia and increased myocardial contractility. Other phenomena include blood flow redistribution (to heart and brain) and an increased oxygen extraction ratio (reflected by a decrease in mixed venous saturation $\left[\mathrm{SvO}_{2}\right]$ ). These mechanisms allow healthy humans to tolerate severe degrees of normovolemic anemia [14,15], although side effects, such as arrhythmias or ST changes, can be observed in extreme cases $[16,17]$. The myocardium is the organ at risk in cases of acute anemia in which both tachycardia and increased ventricle contractility may increase myocardial oxygen demand. Because myocardial oxygen extraction is already almost maximal at rest, every increase in myocardial oxygen demand must be accompanied by increased coronary blood flow [18]. This can become problematic in patients with stenotic coronary arteries especially when tachycardia is present, which can decrease diastoledependent left ventricle perfusion.

Therefore, in critically ill patients, especially those with heart failure or coronary artery disease (CAD), the myocardium may not tolerate such low hemoglobin levels [19]. In acute myocardial infarction, anemia may worsen myocardial ischemia, generate arrhythmias, and potentially increase infarct size [20]. In patients with acute coronary syndrome or heart failure, anemia increases morbidity and mortality [21,22]. For these reasons, patients with cardiac problems should be managed with a more liberal approach to transfusion than other patients $[23,24]$.

\section{Purpose and efficacy of blood transfusion}

The primary purpose of blood transfusion is to increase $\mathrm{DO}_{2}$, which is determined by cardiac output and arterial content of oxygen, the latter being dependent on the hemoglobin level. Hence, blood transfusions can, theoretically at least, limit tissue hypoxia $[13,25,26]$. But does this really happen in clinical practice? It is obvious that RBC transfusions can be lifesaving in situations of acute severe anemia or in bleeding patients in whom $\mathrm{RBC}$ administration can increase both oxygen arterial content and cardiac output. However, in the absence of bleeding, the increase in hemoglobin concentration could very well be offset by a decrease in cardiac output because of the increase in blood viscosity associated with a decreased sympathetic response $[27,28] . \mathrm{DO}_{2}$ has been shown to increase following RBC transfusion in numerous studies [26], but not in all [29].

The effects of $\mathrm{RBC}$ transfusion on the relationship between $\mathrm{DO}_{2}$ and oxygen uptake $\left(\mathrm{VO}_{2}\right)$ are even more difficult to predict. Some studies reported that $\mathrm{VO}_{2}$ increased following $\mathrm{RBC}$ transfusion, whereas others did not [26], and variable effects have been reported on tissue perfusion as assessed by gastric mucosal $\mathrm{pH}$ or near-infrared spectroscopy (NIRS) [30]. The reasons for these contradictory results lie primarily in the degree of severity of hypoxia preceding the RBC transfusion [31], which influences the dependency of $\mathrm{VO}_{2}$ on $\mathrm{DO}_{2}$. Methodological problems (imprecision in determination of $\mathrm{VO}_{2}$, assessment of global $\mathrm{VO}_{2}$ instead of regional $\mathrm{VO}_{2}$, poor correlation between systemic oxygenation parameters, and oxygenation in the microcirculation [13]) also may contribute to these discrepancies [31].

\section{Safety concerns of blood transfusions Impact on outcome}

Red blood cell transfusions have been associated with worse outcomes in several populations of patients, including critically ill patients. In a recent systematic review of 45 observational studies reporting the impact of transfusions on patient outcome (mortality, infections, acute respiratory distress syndrome [ARDS]) in populations of trauma, general surgery, orthopedic surgery, acute coronary syndrome, and ICU patients, Marik and Corwin [32] identified RBC transfusion as an independent predictor of death (pooled odds ratio (OR) from 12 studies, 1.7; 95\% confidence interval (CI), 1.4-1.9), infectious complications (pooled OR from 9 studies, 1.8; 95\% CI, 1.5-2.2), and ARDS (pooled OR from 6 studies, 2.5; 95\% CI, 1.6-3.3). In ICU patients, the three studies included in the review (ABC study [3], CRIT study [5], and a study by Gong et al. [33]) consistently showed a statistically significant association of RBC transfusion with mortality.

On the other hand, analysis of data from a multicenter, prospective, observational study of 3,147 patients in 198 European ICUs (the SOAP study) indicated that 
blood transfusions were not associated with increased mortality by multivariate analysis or propensity matching [34]. In contrast, an extended Cox proportional hazard analysis showed that patients who received a transfusion in fact had a better survival, all factors being otherwise equal. An increased rate of transfused leukoreduced RBCs reported in this study (in which $76 \%$ of centers routinely used leukoreduced RBCs) could perhaps account for the differences between the earlier ABC study [3] (in which $46 \%$ of centers used leukodepleted blood most of the time) and the SOAP study [34]. It also is possible that transfusion thresholds have become so low that the benefits of blood transfusion outweigh the risks.

In patients with acute coronary syndrome, several studies have shown poorer outcomes, including increased mortality, in transfused groups compared with nontransfused patients after adjustment for potential confounders [21,35-37]; similar findings have been reported in patients who undergo percutaneous coronary interventions (PCI) [38]. However, although still controversial, $\mathrm{RBC}$ transfusions may be useful in subgroups of elderly patients with acute myocardial infarction [39] or patients with ST elevation myocardial infarction (STEMI) [21].

Patients who undergo cardiac surgery seem to have worse outcomes when transfused, including higher mortality $[40,41]$, increased occurrence of postoperative infections $[41,42]$, increased time on mechanical ventilation $[40,43]$, and higher incidence of postoperative acute kidney injury $[41,44]$.

Other studies have reported that trauma patients $[45,46]$, including those with burns [47], may have increased mortality rates associated with receiving blood transfusions. In contrast, RBC transfusion has been reported to be associated with improved outcomes in patients with traumatic brain injury or subarachnoid hemorrhage $[48,49]$. In the early resuscitation of patients with severe sepsis, implementation of a therapeutic protocol that included RBC transfusion to obtain a hematocrit $>30 \%$ was associated with a significant reduction in hospital mortality [50].

These results should be interpreted with caution, because most of these data come from observational, retrospective studies, which are subject to numerous biases and sometimes control poorly for confounders, despite the use of various statistical tools, such as logistic regression [51]. It is clear that analyses should not include only admission data. For example, in a welldefined patient population, such as after cardiac surgery, patients who develop gastrointestinal bleeding and require a blood transfusion have a worse prognosis, which is not necessarily the result of the blood transfusion. It is of paramount importance that all risks factors are taken into account. Ruttinger et al. [52] illustrated this point very well. In a series of more than 3,000 surgical patients, these authors showed by using a limited multivariable analysis that transfusions were associated with a worse outcome, but a more complete analysis cancelled out this statistical observation.

\section{Noninfectious serious hazards of transfusions}

The reasons for the apparent worse outcome of transfused compared with nontransfused critically ill patients may be found in several detrimental effects of transfused blood, globally referred to under the acronym "NonInfectious Serious Hazards Of Transfusion" or NISHOT (Table 2) [53]. These include, among others, deleterious effects on the immune system (transfusion-related immunomodulation or "TRIM") or on the cardiopulmonary system, e.g., transfusion-related acute lung injury ("TRALI") [54] or transfusion-associated circulatory overload ("TACO"); the latter is currently the leading reported cause of transfusion-associated mortality [55]. These effects may be enhanced by pathologic conditions (e.g., sepsis) in which the microcirculation is impaired [56] and/or when the RBCs have been stored for some time.

\section{Question of RBC storage}

During storage, RBCs undergo a series of biological and biochemical changes collectively referred to as "the storage lesion" [57]. This includes intracellular changes (progressive depletion of 2,3-diphosphoglycerate [2,3DPG] with increased affinity of hemoglobin for oxygen, depletion of ATP), membrane changes (membrane vesiculation, morphological changes eventually leading to irreversibly deformed spheroechinocytes, lipid peroxidation and increased expression of phosphatidylserine, decreased deformability), and changes in the storage medium (decreased $\mathrm{pH}$, increased potassium, release of proinflammatory cytokines). These stored RBCs also have an increased tendency to adhere to endothelium and could promote vasoconstriction; the stored RBCs act as a "sink" for nitric oxide [58]. Some animal studies [13] have shown deleterious effects of old RBCs on the microcirculation (potentially leading to tissue hypoxia and organ dysfunction). A human study found an inverse correlation between the age of transfused RBCs and maximal change in gastric mucosal $\mathrm{pH}$, but these findings were challenged in subsequent studies [59-61].

The clinical consequences of storage lesions are still not clear. A recent review of the literature [57] identified 24 studies that address the effects of RBC length of storage on clinical (mortality, infections, length of stay, length of mechanical ventilation) or physiological (microcirculation, gastric mucosal $\mathrm{pH}$ ) endpoints. Some studies found associations between the age of transfused 
Table 2 Selected infectious and non-infectious hazards of RBC transfusion in the ICU environment

\begin{tabular}{|c|c|c|}
\hline & $\begin{array}{l}\text { Estimated frequency (event/no. of } \\
\text { transfusions)* }\end{array}$ & Comment \\
\hline \multicolumn{3}{|l|}{ Infectious transmission $[89,90]$} \\
\hline HIV & $1 / 2.310^{6}$ & \\
\hline HBV & $1 / 350000$ & \\
\hline $\mathrm{HCV}$ & $1 / 1.810^{6}$ & \\
\hline HTLV $1 / 2$ & $1 / 210^{6}$ & \\
\hline Bacterial contamination & $1 / 14,000$ to $1 / 28,000$ & GNB such as Y. Enterocolitica mostly encountered \\
\hline \multicolumn{3}{|l|}{ Noninfectious complications } \\
\hline \multicolumn{3}{|l|}{ Immune-mediated $[53,89]$} \\
\hline $\begin{array}{l}\text { Acute hemolytic transfusion } \\
\text { reactions }\end{array}$ & $1 / 10,000$ to $1 / 50,000$ & Most frequently due to $\operatorname{lgM}$, sometimes lgG \\
\hline $\begin{array}{l}\text { Febrile nonhemolytic } \\
\text { transfusion reactions }\end{array}$ & $1 / 500$ & Reduced incidence with prestorage leukoreduction \\
\hline Anaphylactic reactions & $1 / 20,000$ to $1 / 50,000$ & May be associated with IgA deficiency \\
\hline $\begin{array}{l}\text { Transfusion-related acute } \\
\text { lung injury (TRALI) }\end{array}$ & $\begin{array}{l}\text { Highly variable (e.g., 1/29,000 [91], 1/46,700 [92], } \\
1 / 173,000 \text { [93] units transfused) }\end{array}$ & Must be differentiated from TACO \\
\hline Posttransfusion purpura & $1 / 143,000$ & Rare; occurs 5-10 days after transfusion \\
\hline $\begin{array}{l}\text { Transfusion-associated graft } \\
\text { versus host disease }\end{array}$ & $\begin{array}{l}\text { Rare (prevention by irradiation } \\
\text { of blood products) }\end{array}$ & Mostly in immunocompromised hosts, poor prognosis \\
\hline \multicolumn{3}{|l|}{ Nonimmune-mediated $[89,94]$} \\
\hline $\begin{array}{l}\text { Incorrect blood component } \\
\text { transfused (IBCT) }\end{array}$ & $9.7 / 100,000$ components & $\begin{array}{l}\text { Remains frequent despite prevention strategies; must be } \\
\text { differentiated from near-miss transfusion }\end{array}$ \\
\hline $\begin{array}{l}\text { Transfusion-associated } \\
\text { circulatory overload (TACO) }\end{array}$ & Up to $1 \%$ of transfusions & Major cause of transfusion-related death \\
\hline Hyperkalemia & & Mainly after transfusion in newborns \\
\hline \multicolumn{3}{|l|}{ Hypocalcemia - hypothermia } \\
\hline $\begin{array}{l}\text { Dilutional coagulopathy/ } \\
\text { thrombocytopenia }\end{array}$ & & Mainly after massive transfusion \\
\hline
\end{tabular}

HIV human immunodeficiency virus; HBV hepatitis B virus; HCV hepatitis C virus; HTLV human T lymphotropic virus; GNB Gram-negative bacteria

*Frequencies may vary among studies and are only indicative

RBCs and poorer outcomes, whereas others did not. Overall, no clear detrimental effect of RBC age could be identified; however, definitive conclusions are difficult to obtain because of numerous statistical limitations and biases inherent to the study designs $[51,62]$. Several, large, randomized, controlled trials in adult ICU and cardiac surgery patients are currently ongoing to address the clinical relevance of RBC storage. In the multicenter, double-blind prospective ABLE (Age of Blood Evaluation) study [63], adult patients admitted to the ICU are randomly assigned to receive leukoreduced RBCs stored for less than 7 days or issued according to standard procedure (expected average storage time of 19 days). The primary endpoint of this study is 90-day all-cause mortality. The target number of patients is 2,510 (for an expected improvement in primary endpoint greater than 5\%) with an anticipated completion date by April 2013. The Red Cell Storage Duration Study (RECESS) is a multicenter, randomized study in patients (age 12 years and older) who undergo complex cardiac surgery and are likely to require RBC transfusion [64]. Patients who need transfusion are randomized to receive RBCs stored for $\leq 10$ days or $\geq 21$ days. The primary endpoint of this study is the change in the Multiple Organ Dysfunction Score (MODS) from baseline to day 7, with secondary outcomes including all-cause 28-day mortality. The target number of patients is 1,832 , and the anticipated completion date is September 2013.

The results of these trials, especially if older blood appears to be harmful, could have important logistic implications for blood banks $[65,66]$.

\section{Question of leukoreduction}

Many of the adverse effects associated with the transfusion of allogeneic RBCs have been shown to be related to the infusion of white blood cells (WBCs) present in the blood product. Leukoreduction is a process in which WBCs are reduced in number through centrifugation or filtration [67]. This process allows removal of approximately $99.995 \%$ of WBCs, but several thousand leukocytes $(0.005 \%$ of a $500 \mathrm{ml}$ blood unit) may still be present in the processed blood [67]; hence, the word "leukoreduction" is better than "deleukocytation." The beneficial effects of this process include decreased 
febrile nonhemolytic transfusion reactions, decreased transmission of certain pathogens, such as Epstein-Barr virus (EBV) or cytomegalovirus (CMV), parasites and prions [67], and possibly decreased lung injury, such as TRALI. Moreover, prestorage leukoreduction, in which WBC removal occurs before $\mathrm{RBC}$ storage, avoids the need for a leukodepletion filter during transfusion [67] (but a 170-200- $\mu \mathrm{m}$ filter still needs to be incorporated into the intravenous blood line).

In several studies, prestorage leukoreduction decreased $\mathrm{RBC}$ storage lesions, with fewer immunomodulating properties [68] and less adhesion of stored RBCs to the endothelium [69]. A clinical benefit of leukoreduction is still somewhat controversial, particularly in the critically ill patient where no randomized, controlled trial has been performed [70]. In a before-after study of 14,786 patients who underwent cardiac surgery, repair of hip fracture, or who required intensive care after surgery, there was a $1 \%$ decrease in mortality rate associated with the implementation of universal leukoreduction [71]. In a recent meta-analysis of nine RCTs involving 3,093 surgical patients, the use of leukoreduction significantly reduced the odds of postoperative infection (summary OR, 0.522; 95\% CI, 0.332-0.821; $p=0.005$ ) [72]. This observation had been suggested in a previous meta-analysis [73] but has been challenged by another recent meta-analysis [74]. Nevertheless, leukoreduction makes sense, and many countries have adopted it as routine, even though costs are elevated. In Europe, at the time of the SOAP study in 2002, $76 \%$ of centers reported using leukodepleted blood routinely [34], whereas an earlier study performed in the same countries reported lower rates [3].

\section{The decision to transfuse}

Classically, the decision to transfuse is driven by arbitrary "triggers" (hemoglobin level) rather than clinical or physiologic findings. Data from the CRIT study [5], in which there was little evidence that age or comorbidities significantly influenced transfusion practice, tend to support this view.

Current recommendations for RBC transfusion [75,76] are mainly based on the famous "TRICC" (Transfusion Requirements In Critical Care) trial in which patients assigned to a restrictive transfusion strategy (transfusion if hemoglobin level $<7 \mathrm{~g} / \mathrm{dl}$ ) had similar 30-day mortality rates (and even lower mortality in subgroups with APACHE II $<20$ and patients younger than age 55 years) than patients transfused according to a more liberal strategy (transfusion if hemoglobin level $<10 \mathrm{~g} / \mathrm{dl}$ ) [77]. In cardiac surgery patients, the recent randomized, monocenter "TRACS" (Transfusion Requirements after Cardiac Surgery) trial, which compared a restrictive to a liberal strategy (transfusion when hematocrit $<24 \%$ or
$<30 \%$, respectively), reported no difference in the primary endpoint (composite of 30-day mortality and morbidity [cardiogenic shock, ARDS, acute kidney injury]) between the groups [78].

However, it is quite clear there is no "magic" hemoglobin or hematocrit trigger, and for the same level of hemoglobin, some patients will do well, whereas others will not. Thus, the decision to transfuse a patient should be individualized, taking into account several factors, including signs and symptoms of tissue hypoxia (angina pectoris, cognitive dysfunction diagnosed by neuropsychological tests, or increased P300 latencies [79-81]), increased blood lactate levels [82], or electrocardiographic changes suggestive of myocardial ischemia.

Indirect measures of oxygenation, such as a decreased $\mathrm{SvO}_{2}$ or central venous oxygen saturation $\left(\mathrm{ScvO}_{2}\right)$, also may be considered [82]. For example, in a study of early goal-directed therapy in patients with severe sepsis or septic shock admitted to an emergency department, a decrease in $\mathrm{ScvO}_{2}<70 \%$ initiated a therapeutic intervention, including fluid resuscitation, inotropes, vasopressors, and RBC transfusion to increase hematocrit to $>30 \%$ [50]. Use of a decreased ratio of cardiac index to oxygen extraction $\left(\mathrm{CI} / \mathrm{EO}_{2}\right.$ ratio) may be better, because this parameter also reflects the cardiac response to anemia [83].

\section{Economic aspects of blood transfusion}

The costs of blood transfusion are particularly complex to assess because of the many factors that have to be taken into consideration (blood collection and screening for pathogens; blood component processing, including leukoreduction, storage, transport to the transfusion facility; administration of blood to the patient; management of potential short- and long-term transfusion-related side effects) [84]. The subtype of the blood unit also may play a role because some products, such as CMV-negative or autologous units, are costlier than classical allogeneic RBCs. Consequently, studies in this field have given extremely varied results, which are not easily comparable.

Evidence has shown increased costs of RBC transfusion over time [85], related to various factors, including (but not limited to) use of leukoreduction and more sophisticated methods for pathogen detection, such as nucleic acid testing (NAT) [84]. For example, a study in Canada evaluated the mean societal cost of one allogeneic RBC unit at 264.81 US\$, twice the cost estimated 7 years earlier [86]. Generally, these reported values are probably underestimated, and some have calculated that the cost of blood to society could in fact be twofold higher [84].

\section{Alternatives to blood transfusion}

Because of limited availability, costs and safety concerns related to blood transfusion, several strategies to reduce 
blood transfusions can be considered in addition to increasing transfusion trigger thresholds. These include approaches to reduce blood losses, for example use of antifibrinolytic agents, such as tranexamic acid or epsilon-aminocaproic acid (EACA) and techniques of cell salvage during surgery; also, the use of small volume sample tubes can limit the blood losses related to sampling for laboratory studies. In a meta-analysis of 9 randomized controlled trials [87], subcutaneous administration of recombinant erythropoietin (EPO) in critically ill patients was shown to be associated with decreased transfusion rates, but this was not associated with improved mortality (except possibly in a subgroup of trauma patients [88]). Concerns also have been raised about potentially increased rates of deep vein thrombosis [88]. The development of artificial oxygen carriers is under investigation, but these have their own problems [89]. Further research is needed to improve these alternative strategies.

\section{Conclusions}

$\mathrm{RBC}$ transfusion can be lifesaving. During the past two decades, however, safety concerns have emerged, with suggestions that morbidity and mortality may be increased in patients who receive blood transfusions. Therefore, the decision to transfuse should be individualized, based on a rational approach and taking into account physiologic variables in addition to the hemoglobin value. This strategy, along with the use of alternatives whenever possible to limit bleeding, should limit unnecessary exposure to RBCs.

\section{Authors' contributions \\ $\mathrm{CL}$ drafted the manuscript. The manuscript was revised for intellectual content by JLV. Both authors read and approved the final manuscript.}

\section{Competing interests}

The authors declare that they have no competing interests.

Received: 29 July 2011 Accepted: 4 October 2011

Published: 4 October 2011

\section{References}

1. Corwin HL, Surgenor SD, Gettinger A: Transfusion practice in the critically ill. Crit Care Med 2003, 31:S668-671.

2. Walsh TS, Lee RJ, Maciver CR, Garrioch M, Mackirdy F, Binning AR, Cole S, McClelland DB: Anemia during and at discharge from intensive care: the impact of restrictive blood transfusion practice. Intensive Care Med 2006, 32:100-109.

3. Vincent J-L, Baron JF, Reinhart K, Gattinoni L, Thijs L, Webb A, MeierHellmann A, Nollet G, Peres-Bota D: Anemia and blood transfusion in critically ill patients. JAMA 2002, 288:1499-1507.

4. Nguyen BV, Bota DP, Melot C, Vincent JL: Time course of hemoglobin concentrations in nonbleeding intensive care unit patients. Crit Care Med 2003, 31:406-410.

5. Corwin HL, Gettinger A, Pearl RG, Fink MP, Levy MM, Abraham E, Maclntyre NR, Shabot MM, Duh MS, Shapiro MJ: The CRIT Study: anemia and blood transfusion in the critically ill-Current clinical practice in the United States. Crit Care Med 2004, 32:32-52.
6. Rao MP, Boralessa H, Morgan C, Soni N, Goldhill DR, Brett SJ, Contreras M: Blood component use in critically ill patients. Anaesthesia 2002, 57:530-534.

7. Walsh TS, Garrioch M, Maciver C, Lee RJ, Mackirdy F, McClelland DB, Kinsella J, Wallis C: Red cell requirements for intensive care units adhering to evidence-based transfusion guidelines. Transfusion 2004, 44:1405-1411.

8. Westbrook A, Pettila V, Nichol A, Bailey MJ, Syres G, Murray L, Bellomo R, Wood E, Phillips LE, Street A, French C, Orford N, Santamaria J, Cooper DJ: Transfusion practice and guidelines in Australian and New Zealand intensive care units. Intensive Care Med 2010, 36:1138-1146.

9. Hebert PC, Wells G, Martin C, Tweeddale M, Marshall J, Blajchman M, Pagliarello G, Sandham D, Schweitzer II, Boisvert D, Calder L: Variation in red cell transfusion practice in the intensive care unit: a multicentre cohort study. Crit Care 1999, 3:57-63.

10. French CJ, Bellomo R, Finfer SR, Lipman J, Chapman M, Boyce NW: Appropriateness of red blood cell transfusion in Australasian intensive care practice. Med J Aust 2002, 177:548-551.

11. Scharte M, Fink MP: Red blood cell physiology in critical illness. Crit Care Med 2003, 31:S651-657.

12. Piagnerelli M, Boudjeltia KZ, Brohee D, Piro P, Carlier E, Vincent JL, Lejeune $P$, Vanhaeverbeek M: Alterations of red blood cell shape and sialic acid membrane content in septic patients. Crit Care Med 2003, 31:2156-2162.

13. Raat NJ, Ince C: Oxygenating the microcirculation: the perspective from blood transfusion and blood storage. Vox Sang 2007, 93:12-18.

14. Fontana IL, Welborn L, Mongan PD, Sturm P, Martin G, Bunger R: Oxygen consumption and cardiovascular function in children during profound intraoperative normovolemic hemodilution. Anesth Analg 1995, 80:219-225.

15. Zollinger A, Hager $P$, Singer T, Friedl HP, Pasch T, Spahn DR: Extreme hemodilution due to massive blood loss in tumor surgery. Anesthesiology 1997, 87:985-987.

16. Leung JM, Weiskopf RB, Feiner J, Hopf HW, Kelley S, Viele M, Lieberman J, Watson J, Noorani M, Pastor D, Yeap H, Ho R, Toy P: Electrocardiographic ST-segment changes during acute, severe isovolemic hemodilution in humans. Anesthesiology 2000, 93:1004-1010.

17. Weiskopf RB, Viele MK, Feiner J, Kelley S, Lieberman J, Noorani M, Leung JM, Fisher DM, Murray WR, Toy P, Moore MA: Human cardiovascular and metabolic response to acute, severe isovolemic anemia. JAMA 1998, 279:217-221

18. Madjdpour C, Spahn DR: Allogeneic red blood cell transfusion: physiology of oxygen transport. Best Pract Res Clin Anaesthesiol 2007, 21:163-171.

19. Levy PS, Kim SJ, Eckel PK, Chavez R, Ismail EF, Gould SA, Ramez Salem M, Crystal GJ: Limit to cardiac compensation during acute isovolemic hemodilution: influence of coronary stenosis. Am J Physiol 1993, 265: H340-349.

20. Kurek T, Lenarczyk R, Kowalczyk J, Swiatkowski A, Kowalski O, StabrylaDeska J, Honisz G, Lekston A, Kalarus Z, Kukulski T: Effect of anemia in high-risk groups of patients with acute myocardial infarction treated with percutaneous coronary intervention. Am J Cardiol 2010, 105:611-618.

21. Sabatine MS, Morrow DA, Giugliano RP, Burton PB, Murphy SA, McCabe $\mathrm{CH}$, Gibson CM, Braunwald E: Association of hemoglobin levels with clinical outcomes in acute coronary syndromes. Circulation 2005, 111:2042-2049.

22. Lindenfeld J: Prevalence of anemia and effects on mortality in patients with heart failure. Am Heart J 2005, 149:391-401.

23. Walsh TS, McClelland DB, Lee RJ, Garrioch M, Maciver CR, McArdle F Crofts SL, Mellor I: Prevalence of ischaemic heart disease at admission to intensive care and its influence on red cell transfusion thresholds: multicentre Scottish Study. Br J Anaesth 2005, 94:445-452.

24. Hebert $P C$, Fergusson DA, Stather D, McIntyre L, Martin C, Doucette $S$, Blajchman M, Graham ID: Revisiting transfusion practices in critically ill patients. Crit Care Med 2005, 33:7-12.

25. Vincent $\mathrm{JL}$, Piagnerelli M: Transfusion in the intensive care unit. Crit Care Med 2006, 34:S96-101.

26. Tinmouth A, Fergusson D, Yee IC, Hebert PC: Clinical consequences of red cell storage in the critically ill. Transfusion 2006, 46:2014-2027.

27. English M, Ahmed M, Ngando C, Berkley J, Ross A: Blood transfusion for severe anaemia in children in a Kenyan hospital. Lancet 2002, 359:494-495. 
28. Martini J, Carpentier B, Negrete AC, Frangos JA, Intaglietta M: Paradoxical hypotension following increased hematocrit and blood viscosity. Am J Physiol Heart Circ Physiol 2005, 289:H2136-2143.

29. Shah DM, Gottlieb ME, Rahm RL, Stratton HH, Barie PS, Paloski WH, Newell JC: Failure of red blood cell transfusion to increase oxygen transport or mixed venous PO2 in injured patients. J Trauma 1982, 22:741-746.

30. Creteur J, Neves AP, Vincent JL: Near-infrared spectroscopy technique to evaluate the effects of red blood cell transfusion on tissue oxygenation. Crit Care 2009, 13(Suppl 5):S11.

31. Pape A, Stein P, Horn O, Habler O: Clinical evidence of blood transfusion effectiveness. Blood Transfus 2009, 7:250-258.

32. Marik PE, Corwin HL: Efficacy of red blood cell transfusion in the critically ill: a systematic review of the literature. Crit Care Med 2008, 36:2667-2674.

33. Gong MN, Thompson BT, Williams P, Pothier L, Boyce PD, Christiani DC: Clinical predictors of and mortality in acute respiratory distress syndrome: potential role of red cell transfusion. Crit Care Med 2005, 33:1191-1198.

34. Vincent JL, Sakr Y, Sprung C, Harboe S, Damas P: Are blood transfusions associated with greater mortality rates? Results of the Sepsis Occurrence in Acutely III Patients study. Anesthesiology 2008, 108:31-39.

35. Singla I, Zahid M, Good CB, Macioce A, Sonel AF: Impact of blood transfusions in patients presenting with anemia and suspected acute coronary syndrome. Am J Cardiol 2007, 99:1119-1121.

36. Yang X, Alexander KP, Chen AY, Roe MT, Brindis RG, Rao SV, Gibler WB, Ohman EM, Peterson ED: The implications of blood transfusions for patients with non-ST-segment elevation acute coronary syndromes: results from the CRUSADE National Quality Improvement Initiative. J Am Coll Cardiol 2005, 46:1490-1495.

37. Rao SV, Jollis JG, Harrington RA, Granger CB, Newby LK, Armstrong PW, Moliterno DJ, Lindblad L, Pieper K, Topol EJ, Stamler JS, Califf RM: Relationship of blood transfusion and clinical outcomes in patients with acute coronary syndromes. JAMA 2004, 292:1555-1562.

38. Nikolsky E, Mehran R, Sadeghi HM, Grines CL, Cox DA, Garcia E, Tcheng JE, Griffin JJ, Guagliumi G, Stuckey T, Turco M, Fahy M, Lansky AJ, Stone GW: Prognostic impact of blood transfusion after primary angioplasty for acute myocardial infarction: analysis from the CADILLAC (Controlled Abciximab and Device Investigation to Lower Late Angioplasty Complications) Trial. JACC Cardiovasc Interv 2009, 2:624-632.

39. Wu WC, Rathore SS, Wang Y, Radford MJ, Krumholz HM: Blood transfusion in elderly patients with acute myocardial infarction. N Engl J Med 2001, 345:1230-1236.

40. Kuduvalli M, Oo AY, Newall N, Grayson AD, Jackson M, Desmond MJ, Fabri BM, Rashid A: Effect of peri-operative red blood cell transfusion on 30-day and 1-year mortality following coronary artery bypass surgery. Eur J Cardiothorac Surg 2005, 27:592-598.

41. Koch CG, Li L, Duncan Al, Mihaljevic T, Cosgrove DM, Loop FD, Starr NJ, Blackstone EH: Morbidity and mortality risk associated with red blood cell and blood-component transfusion in isolated coronary artery bypass grafting. Crit Care Med 2006, 34:1608-1616.

42. Leal-Noval SR, Rincon-Ferrari MD, Garcia-Curiel A, Herruzo-Aviles A Camacho-Larana P, Garnacho-Montero J, Amaya-Villar R: Transfusion of blood components and postoperative infection in patients undergoing cardiac surgery. Chest 2001, 119:1461-1468.

43. Vamvakas EC, Carven JH: Allogeneic blood transfusion and postoperative duration of mechanical ventilation: effects of red cell supernatant, platelet supernatant, plasma components and total transfused fluid. Vox Sang 2002, 82:141-149.

44. Habib RH, Zacharias A, Schwann TA, Riordan CJ, Engoren M, Durham SJ, Shah A: Role of hemodilutional anemia and transfusion during cardiopulmonary bypass in renal injury after coronary revascularization: implications on operative outcome. Crit Care Med 2005, 33:1749-1756.

45. Malone DL, Dunne J, Tracy JK, Putnam AT, Scalea TM, Napolitano LM: Blood transfusion, independent of shock severity, is associated with worse outcome in trauma. J Trauma 2003, 54:898-905.

46. Croce MA, Tolley EA, Claridge JA, Fabian TC: Transfusions result in pulmonary morbidity and death after a moderate degree of injury. $J$ Trauma 2005, 59:19-23.

47. Palmieri TL, Caruso DM, Foster KN, Cairns BA, Peck MD, Gamelli RL, Mozingo DW, Kagan RJ, Wahl W, Kemalyan NA, Fish JS, Gomez M, Sheridan RL, Faucher LD, Latenser BA, Gibran NS, Klein RL, Solem LD,
Saffle JR, Morris SE, Jeng JC, Voigt D, Howard PA, Molitor F, Greenhalgh DG: Effect of blood transfusion on outcome after major burn injury: a multicenter study. Crit Care Med 2006, 34:1602-1607.

48. Zygun DA, Nortje J, Hutchinson PJ, Timofeev I, Menon DK, Gupta AK: The effect of red blood cell transfusion on cerebral oxygenation and metabolism after severe traumatic brain injury. Crit Care Med 2009, 37:1074-1078.

49. Smith MJ, Stiefel MF, Magge S, Frangos S, Bloom S, Gracias V, Le Roux PD: Packed red blood cell transfusion increases local cerebral oxygenation. Crit Care Med 2005, 33:1104-1108.

50. Rivers E, Nguyen B, Havstad S, Ressler J, Muzzin A, Knoblich B, Peterson E, Tomlanovich M: Early goal-directed therapy in the treatment of severe sepsis and septic shock. N Engl J Med 2001, 345:1368-1377.

51. Middelburg RA, van de Watering LM, van der Bom JG: Blood transfusions: good or bad? Confounding by indication, an underestimated problem in clinical transfusion research. Transfusion 2010, 50:1181-1183.

52. Ruttinger $\mathrm{D}$, Wolf $\mathrm{H}$, Kuchenhoff $\mathrm{H}$, Jauch KW, Hartl WH: Red cell transfusion: an essential factor for patient prognosis in surgical critical illness? Shock 2007, 28:165-171.

53. Hendrickson JE, Hillyer CD: Noninfectious serious hazards of transfusion. Anesth Analg 2009, 108:759-769

54. Benson AB, Moss M, Silliman CC: Transfusion-related acute lung injury (TRALI): a clinical review with emphasis on the critically ill. Br J Haematol 2009, 147:431-443

55. Knowles $\mathrm{S}$, Cohen $\mathrm{H}$, on behalf of the Serious Hazards of Transfusion (SHOT) Steering Group: The 2010 Annual SHOT Report.[http://www.shotuk. org/wp-content/uploads/2011/07/SHOT-2010-Report.pdf].

56. De Backer D, Creteur J, Preiser JC, Dubois MJ, Vincent JL: Microvascular blood flow is altered in patients with sepsis. Am J Respir Crit Care Med 2002, 166:98-104.

57. Lelubre C, Piagnerelli M, Vincent JL: Association between duration of storage of transfused red blood cells and morbidity and mortality in adult patients: myth or reality? Transfusion 2009, 49:1384-1394.

58. Bennett-Guerrero E, Veldman TH, Doctor A, Telen MJ, Ortel TL, Reid TS, Mulherin MA, Zhu H, Buck RD, Califf RM, McMahon TJ: Evolution of adverse changes in stored RBCs. Proc Natl Acad Sci 2007, 104:17063-17068.

59. Marik PE, Sibbald WJ: Effect of stored-blood transfusion on oxygen delivery in patients with sepsis. JAMA 1993, 269:3024-3029.

60. Walsh TS, McArdle F, McLellan SA, Maciver C, Maginnis M, Prescott RJ, McClelland DB: Does the storage time of transfused red blood cells influence regional or global indexes of tissue oxygenation in anemic critically ill patients? Crit Care Med 2004, 32:364-371

61. Fernandes CJ, Akamine N, De Marco FV, De Souza JA, Lagudis S, Knobel E Red blood cell transfusion does not increase oxygen consumption in critically ill septic patients. Crit Care 2001, 5:362-367.

62. van de Watering L: Pitfalls in the current published observational literature on the effects of red blood cell storage. Transfusion 2011.

63. Lacroix J, Hebert P, Fergusson D, Tinmouth A, Blajchman MA, Callum J, Cook D, Marshall JC, Mclntyre L, Turgeon AF: The Age of Blood Evaluation (ABLE) randomized controlled trial: study design. Transfus Med Rev 2011, 25:197-205.

64. Steiner ME, Assmann SF, Levy JH, Marshall J, Pulkrabek S, Sloan SR, Triulzi D, Stowell CP: Addressing the question of the effect of RBC storage on clinical outcomes: The Red Cell Storage Duration Study (RECESS) (Section 7). Tranfus Apher Sci 2010, 43:107-116.

65. Ness PM: Does transfusion of stored red blood cells cause clinically important adverse effects? A critical question in search of an answer and a plan. Transfusion 2011, 51:666-667.

66. Hebert PC, Chin-Yee I, Fergusson D, Blajchman M, Martineau R, Clinch J, Olberg B: A pilot trial evaluating the clinical effects of prolonged storage of red cells. Anesth Analg 2005, 100:1433-1438.

67. Shapiro MJ: To filter blood or universal leukoreduction: what is the answer? Crit Care 2004, 8(Suppl 2):S27-30

68. Shanwell A, Kristiansson M, Remberger M, Ringden O: Generation of cytokines in red cell concentrates during storage is prevented by prestorage white cell reduction. Transfusion 1997, 37:678-684.

69. Anniss AM, Sparrow RL: Storage duration and white blood cell content of red blood cell (RBC) products increases adhesion of stored RBCs to endothelium under flow conditions. Transfusion 2006, 46:1561-1567.

70. Vincent $\mathrm{J}$, Piagnerelli M: Transfusion in the intensive care unit. Crit Care Med 2006, , 34: S96-101. 
71. Hebert PC, Fergusson D, Blajchman MA, Wells GA, Kmetic A, Coyle D, Heddle N, Germain M, Goldman M, Toye B, Schweitzer I, vanWalraven C, Devine D, Sher GD: Clinical outcomes following institution of the Canadian universal leukoreduction program for red blood cell transfusions. JAMA 2003, 289:1941-1949.

72. Blumberg N, Zhao H, Wang H, Messing S, Heal JM, Lyman GH: The intention-to-treat principle in clinical trials and meta-analyses of leukoreduced blood transfusions in surgical patients. Transfusion 2007, 47:573-581.

73. Fergusson D, Khanna MP, Tinmouth A, Hebert PC: Transfusion of leukoreduced red blood cells may decrease postoperative infections: two meta-analyses of randomized controlled trials. Can J Anaesth 2004, 51:417-424.

74. Vamvakas EC: White-blood-cell-containing allogeneic blood transfusion and postoperative infection or mortality: an updated meta-analysis. Vox Sang 2007, 92:224-232

75. Hebert PC, Tinmouth A, Corwin HL: Controversies in RBC transfusion in the critically ill. Chest 2007, 131:1583-1590.

76. Dellinger RP, Levy MM, Carlet JM, Bion J, Parker MM, Jaeschke R, Reinhart K, Angus DC, Brun-Buisson C, Beale R, Calandra T, Dhainaut JF, Gerlach H, Harvey M, Marini JJ, Marshall J, Ranieri M, Ramsay G, Sevransky J, Thompson BT, Townsend S, Vender JS, Zimmerman JL, Vincent JL: Surviving Sepsis Campaign: international guidelines for management of severe sepsis and septic shock: 2008. Crit Care Med 2008, 36:296-327.

77. Hebert PC, Wells G, Blajchman MA, Marshall J, Martin C, Pagliarello G, Tweeddale M, Schweitzer I, Yetisir E: A multicenter, randomized, controlled clinical trial of transfusion requirements in critical care. Transfusion Requirements in Critical Care Investigators, Canadian Critical Care Trials Group. N Engl J Med 1999, 340:409-417.

78. Hajjar LA, Vincent JL, Galas FR, Nakamura RE, Silva CM, Santos MH, Fukushima J, Kalil Filho R, Sierra DB, Lopes NH, Mauad T, Roquim AC, Sundin MR, Leao WC, Almeida JP, Pomerantzeff PM, Dallan LO, Jatene FB, Stolf NA, Auler JO Jr: Transfusion requirements after cardiac surgery: the TRACS randomized controlled trial. JAMA 2010, 304:1559-1567.

79. Weiskopf RB, Feiner J, Hopf H, Lieberman J, Finlay HE, Quah C, Kramer JH, Bostrom A, Toy P: Fresh blood and aged stored blood are equally efficacious in immediately reversing anemia-induced brain oxygenation deficits in humans. Anesthesiology 2006, 104:911-920.

80. Hare GM: Anaemia and the brain. Curr Opin Anaesthesiol 2004, 17:363-369.

81. Weiskopf RB, Kramer JH, Viele M, Neumann M, Feiner JR, Watson JJ, Hopf HW, Toy P: Acute severe isovolemic anemia impairs cognitive function and memory in humans. Anesthesiology 2000, 92:1646-1652

82. Vallet $B$, Robin $E$, Lebuffe $G$ : Venous oxygen saturation as a physiologic transfusion trigger. Crit Care 2010, 14:213.

83. Yalavatti GS, DeBacker D, Vincent JL: Assessment of cardiac index in anemic patients. Chest 2000, 118:782-787.

84. Shander A, Hofmann A, Gombotz H, Theusinger OM, Spahn DR: Estimating the cost of blood: past, present, and future directions. Best Pract Res Clin Anaesthesiol 2007, 21:271-289.

85. Amin M, Fergusson D, Aziz A, Wilson K, Coyle D, Hebert P: The cost of allogeneic red blood cells-a systematic review. Transfus Med 2003, 13:275-285

86. Amin M, Fergusson D, Wilson K, Tinmouth A, Aziz A, Coyle D, Hebert P: The societal unit cost of allogenic red blood cells and red blood cell transfusion in Canada. Transfusion 2004, 44:1479-1486.

87. Zarychanski R, Turgeon AF, Mclntyre L, Fergusson DA: Erythropoietinreceptor agonists in critically ill patients: a meta-analysis of randomized controlled trials. CMAJ 2007, 177:725-734.

88. Corwin HL, Gettinger A, Fabian TC, May A, Pearl RG, Heard S, An R, Bowers PJ, Burton P, Klausner MA, Corwin MJ: Efficacy and safety of epoetin alfa in critically ill patients. N Engl J Med 2007, 357:965-976.

89. Tinmouth AT, Mclntyre LA, Fowler RA: Blood conservation strategies to reduce the need for red blood cell transfusion in critically ill patients. CMAJ 2008, 178:49-57.

90. Dodd RY: Current risk for transfusion transmitted infections. Curr Opin Hematol 2007, 14:671-676.

91. Van Stein D, Beckers EA, Sintnicolaas K, Porcelijn L, Danovic F, Wollersheim JA, Brand A, Van Rhenen DJ: Transfusion-related acute lung injury reports in the Netherlands: an observational study. Transfusion 2010, 50:213-220.
92. MacDonald N, Scott JW, McCombie N, Robillard P, Giulivi A: Transfusion and risk of infection in Canada: Update 2006. Can J Infect Dis Med Microbiol 2006, 17:103-107

93. Ozier $Y$, Muller JY, Mertes PM, Renaudier $P$, Aguilon $P$, Canivet N, Fabrigli $P$, Rebibo D, Tazerout M, Trophilme C, Willaert B, Caldani C: Transfusionrelated acute lung injury: reports to the French Hemovigilance Network 2007 through 2008. Transfusion 2011, Epub 7/3/11.

94. Stainsby D, Russell J, Cohen H, Lilleyman J: Reducing adverse events in blood transfusion. Br J Haematol 2005, 131:8-12.

doi:10.1186/2110-5820-1-43

Cite this article as: Lelubre and Vincent: Red blood cell transfusion in the critically ill patient. Annals of Intensive Care 2011 1:43.

\section{Submit your manuscript to a SpringerOpen ${ }^{\mathcal{O}}$ journal and benefit from:}

- Convenient online submission

- Rigorous peer review

- Immediate publication on acceptance

- Open access: articles freely available online

- High visibility within the field

- Retaining the copyright to your article

Submit your next manuscript at $>$ springeropen.com 